\title{
MOTIVASI KERJA DAN KINERJA ALUMNUS AKPER ADI HUSADA YANG BEKERJA DI RS ADI HUSADA UNDAAN WETAN SURABAYA
}

\author{
NI PUTU RUSMINI \\ AKADEMI KEPERAWATAN ADI HUSADA SURABAYA
}

\begin{abstract}
Education and development of the nurse is one of the activities to be carried out by the nursing managers to support the performance of nurses, that are expected to improve the quality of nursing care. The performance assessment is a tool that can be trusted in the control of human resources and productivity. The aim of this study was to identify the motivation to work and work performance of AKPER Adi Husada Surabaya ex-students who worked at the Adi Husada Undaan Wetan Hospital and identify relationship between both factors. This study uses correlation design with cross sectional approach, using consecutive sampling technique and obtained a sample of 94 respondents. Data obtained by using questionnaires and result was tested with Spearman Rank test using computer software with a significance $p=0.05$. Statistical test results showed $r=0.443$, it shows the null hypothesis was rejected so that there was a weak relationship between motivation and work performance AKPER Adi Husada Surabaya ex-students who worked at the hospital Adi Husada Undaan Wetan Surabaya. So motivation factor was not the main factor that causes an increase in performance, but the entire internal and external factors greatly affect the performance of individual nurses. Expected nurses can improve motivation and other factors related to the performance becomes more optimized and can improve the quality of nursing care.
\end{abstract}

\section{ABSTRAK}

Pembinaan dan pengembangan terhadap perawat merupakan salah satu kegiatan yang harus dilakukan oleh kepala ruangan atau manajer keperawatan untuk mendukung kinerja perawat, sehingga diharapkan mampu meningkatkan mutu pelayanan keperawatan. Penilaian kinerja merupakan alat yang dapat dipercaya dalam mengontrol sumber daya manusia dan produktivitas. Tujuan dari penelitian ini adalah untuk mengidentifikasi motivasi kerja, kinerja alumnus AKPER Adi Husada Surabaya yang bekerja di RS Adi Husada Undaan Wetan dan hubungan kedua faktor tersebut. Penelitian ini menggunakan desain korelasi dengan pendekatan potong lintang, menggunakan teknik consecutive sampling dan didapatkan sampel sebanyak 94 responden. Data diperoleh dengan menggunakan kuesioner kemudian diuji dengan Spearman Rank test menggunakan software computer dengan signifikansi $p=0,05$. Hasil uji statistic menunjukkan $r=0,443$, hal tersebut menunjukkan hipotesis nol ditolak sehingga ada hubungan namun bersifat lemah antara motivasi kerja dan kinerja alumnus AKPER Adi Husada Surabaya yang bekerja di RS Adi Husada Undaan Wetan Surabaya. Faktor motivasi kerja bukan faktor utama yang menyebabkan peningkatan kinerja namun seluruh faktor internal maupun ekternal individu sangat mempengaruhi kinerja perawat. Diharapkan perawat dapat meningkatkan motivasi kerja dan faktor lain yang terkait sehingga kinerja menjadi lebih optimal dan dapat meningkatkan mutu pelayanan keperawatan.

Keywords: $\quad$ Motivation, Nurse's Duty Job, Quality of Nursing Practice

\section{PENDAHULUAN}

Pembinaan dan pengembangan terhadap perawat merupakan salah satu kegiatan yang harus dilakukan oleh kepala ruangan atau manajer perawatan untuk mendukung kinerja perawat, sehingga diharapkan mampu meningkatkan mutu pelayanan keperawatan. Evaluasi dilakukan untuk memperoleh informasi mengenai hasil yang telah dicapai. Faktor faktor yang mendukung dan hambatan yang dihadapi dalam memberikan pelayanan keperawatan. Penilaian kinerja merupakan alat yang dapat dipercaya oleh manajer perawat dalam mengontrol sumber daya manusia dan produktivitas. $^{1}$ 
Evaluasi penilaian kerja selain berguna untuk audit kinerja perawat juga berguna untuk lembaga pendidikan. Kesuksesan suatu lembaga pendidikan keperawatan yang menghasilkan tenaga perawat yaitu yang dapat bekerja di suatu lembaga kesehatan dengan memberikan pelayanan kesehatan dan memberikan asuhan keperawatan kepada masyarakat yang memerlukan baik sehat maupun sakit. Lembaga pelayanan kesehatan dan keperawatan seperti halnya Rumah Sakit selalu mempunyai tujuan untuk memberikan pelayanan sebaik-baiknya (excellent service) kepada pengguna jasa, sehingga perawat dituntut untuk profesional dan bertanggung jawab dalam memberikan asuhan keperawatan kepada klien, serta perawat harus siap untuk menerima tanggung gugat bila terjadi kelalaian terhadap suatu tindakan keperawatan. Lembaga pendidikan turut serta dalam memberikan pendidikan dasar kepada perawat, sehingga perawat mendapatkan gambaran tentang tantangan yang akan dihadapi setelah menjalani proses pembelajaran, selain itu lembaga pendidikan berperan serta mengevaluasi lulusan akademi perawat guna meningkatkan mutu pendidikan, ketrampilan dan sikap (attitude) serta mengikuti perkembangan jaman. ${ }^{4}$

Akademi Keperawatan Adi Husada Surabaya sendiri telah berdiri selama 32 tahun serta telah meluluskan kurang lebih 1200 orang perawat. Lulusan AKPER Adi Husada ini bekerja menyebar di seluruh Indonesia dan ada yang bekerja di luar negeri seperti Arab Saudi, Australia dan Kuwait. Di Surabaya sendiri, kurang lebih 850 orang perawat lulusan AKPER Adi Husada yang bekerja di rumah sakit negeri dan swasta maupun rumah sakit bertaraf internasional. RS Adi Husada Undaan Wetan sendiri menerima lulusan AKPER Adi Husada sebanyak 300 orang perawat.

Lembaga pendidikan (AKPER Adi Husada) dan RS Adi Husada Undaan Wetan Surabaya dapat berkerjasama untuk melakukan penilaian kinerja perawat lulusan AKPER Adi Husada, hal ini dilakukan untuk kemajuan dan perkembangan kedua belah pihak untuk menjadi lebih baik lagi dalam memberikan pelayanan dan mengembangkan proses pembelajaran dan ketrampilan untuk lembaga pendidikan.

Tujuan dari penelitian ini adalah untuk mengidentifikasi hubungan antara motivasi kerja dengan kinerja alumni AKPER Adi Husada di RS Adi Husada Undaan Wetan Surabaya.

\section{METODE}

Penelitian ini merupakan penelitian korelasi dengan pendekatan potong lintang. Pengambilan sampel dengan menggunakan teknik consecutive sampling. Sampel yang didapatkan sebanyak 94 responden. Kriteria sampel, antara lain: alumnus DIII Keperawatan AKPER Adi Husada Surabaya, bersedia menjadi responden, bekerja di ruang rawat inap. Data

\begin{tabular}{ccc}
\hline Lama Kerja & F & \% \\
\hline$<1$ tahun & 20 & $21 \%$ \\
\hline $1<3$ tahun & 21 & $22 \%$ \\
\hline $3<6$ tahun & 41 & $44 \%$ \\
\hline$>6$ tahun & 12 & $13 \%$ \\
\hline Total & 94 & $100 \&$
\end{tabular}

diambil menggunakan kuesioner motivasi dan kinerja perawat. Hasil dari pengumpulan data dilakukan uji statistik Spearman Rank Test dengan menggunakan software computer. Penelitian ini menggunakan tingkat signifikansi sebesar $p<0,005$.

\section{HASIL}

Dari seluruh jumlah responden sebanyak 94 orang Alumnus Akper Adi Husada yang bekerja di Rumah Sakit Adi Husada Undaan Wetan Surabaya, dilakukan pendataan dengan karakteristik sebagai berikut:

Tabel 1. Distribusi Responden Berdasarkan Lama Bekerja

Berdasarkan Tabel 1. di atas menunjukan responden dengan lama bekerja 
terbanyak $3<6$ tahun sebanyak 41 responden (44\%).

Tabel 2. Distribusi Responden Berdasarkan Ketrampilan Tambahan

Berdasarkan Tabel 2. menunjukkan bahwa hampir seluruh responden tidak memiliki ketrampilan tambahan yaitu 87 responden (72.5\%).

Tabel 3. Distribusi Responden Berdasarkan Status Pernikahan

\begin{tabular}{ccc}
\hline $\begin{array}{c}\text { Status } \\
\text { Pernikahan }\end{array}$ & $\mathbf{F}$ & $\mathbf{\%}$ \\
\hline Belum & 15 & $16 \%$ \\
\hline Menikah & 79 & $84 \%$ \\
\hline Duda/Janda & 0 & 0 \\
\hline Total & 94 & $100 \%$
\end{tabular}

Berdasarkan Tabel 3. Menunjukkan bahwa sebagian besar sudah menikah yaitu 79 responden (84\%).

Tabel 4. Motivasi Kerja Alumnus AKPER Adi Husada yang Bekerja di RS Adi Husada Undaan Wetan

\begin{tabular}{ccc}
\hline Motivasi Kerja & F & \% \\
\hline Baik & 90 & $96 \%$ \\
\hline Cukup & 4 & $4 \%$ \\
\hline Kurang & 0 & 0 \\
\hline Total & 94 & $100 \%$
\end{tabular}

Berdasarkan data pada gambar 4.1 maka dari 94 responden dengan motivasi kerja baik sebanyak 96\% (90 responden) dan motivasi kerja cukup sebanyak $4 \%$ (4 responden).

Tabel 5. Kinerja Alumnus AKPER Adi Husada yang Bekerja di RS Adi Husada Undaan Wetan

\begin{tabular}{ccc}
\hline Kinerja & F & \% \\
\hline Baik & 64 & $68 \%$
\end{tabular}

\begin{tabular}{ccc}
\hline Cukup & 30 & $32 \%$ \\
\hline Kurang & 0 & 0 \\
\hline Total & 94 & $100 \%$ \\
\hline Ketrampilan & $\mathbf{F}$ & $\mathbf{\%}$ \\
\hline Tambahan & & $92.5 \%$ \\
\hline Ya & 7 & $72.5 \%$ \\
\hline Tidak & 87 & $100 \%$ \\
\hline Total & 94 & \\
\hline
\end{tabular}

Berdasarkan Tabel 5 maka dari 94 responden yang kinerja baik 64 responden (68\%) dan yang kinerja cukup 30 responden (32\%).

Hasil uji statistik menggunakan Spearman Rank hubungan motivasi kerja dengan kinerja alumnus AKPER Adi Husada didapatkan $\mathrm{p}=0.05$ dan $r=0.443$. Artinya Ho ditolak sehingga ada hubungan namun bersifat lemah antara motivasi kerja dengan kinerja Alumnus AKPER Adi Husada di Rumah Sakit Adi Husada Undaan Wetan Surabaya.

\section{PEMBAHASAN}

Nursalam (2008) menyatakan bahwa motivasi merupakan kondisi yang menggerakkan diri pegawai yang terarah untuk mencapai tujuan organisasi (tujuan kerja). Menurut teori Mangkunegara mengatakan motivasi kerja adalah suatu kondisi yang berpengaruh untuk membangkitkan, mengarahkan dan memelihara perilaku yang berhubungan dengan lingkungan kerja.

Seseorang mempunyai motivasi yang baik bila menekuni tugas yang sedang dihadapi, misalnya seorang perawat menerima pasien baru maka perawat tersebut harus melakukan pendekatan dengan menggunakan proses keperawatan mulai dari pengkajian sampai dengan evaluasi, perawat juga harus ulet menghadapi kesulitan dimana perawat tidak lekas putus asa dan tidak lekas puas dengan prestasi yang diperoleh, menunjukkan minat 
terhadap bemacam-macam masalah, dapat mempertahankan pendapat, senang bekerja serta senang mencari dan memecahkan masalah. Seorang perawat akan melaksanakan tugasnya dengan penuh rasa tanggung jawab, selalu care terhadap pasien dan keluarganya karena bekerja adalah suatu bentuk aktivitas yang bertujuan untuk mendapatkan kepuasan. Perawat akan merasa senang jika pasien itu puas dengan pelayanan yang telah di berikan. Motivasi juga terbentuk dari sikap (attidute) seorang pegawai dalam menghadapi situasi (situation) kerja. Sikap mental seorang pegawai harus sikap mental yang siap secara psikofisik yaitu siap secara mental, fisik, tujuan dan situasi. Seorang pegawai harus siap mental, mampu secara fisik, memahami tujuan utama dan target kerja yang akan dicapai, mampu memanfaatkan dan menciptakan situasi kerja yang kondusif. Sikap mental yang siap secara psikofisik terbentuk karena pegawai mempunyai modal dan kreatifitas. Dengan demikian pegawai tersebut mampu mengolah otak dengan aktif dan lincah, memiliki keinginan maju, rasa ingin tahu tinggi, energik, analisis sistematik, terbuka untuk menerima pendapat, inisiatif tinggi dan pikiran luas terarah. Hal ini didukung oleh usia responden terbanyak 29 responden (31\%) yaitu 23-25 tahun. Menurut Hurlock (1989) bahwa semakin cukup umur seseorang makin tinggi tingkat kematangan dan kekuatan seseorang dalam berfikir dan bekerja. ${ }^{3}$ Pada usia tersebut adalah usia produktif yang menghasilkan banyak edukasi, inovasi sehingga membangkitkan motivasi yang baik dalam bekerja. Didukung juga dengan lama bekerja terbanyak $3<6$ tahun 41 responden (24\%) dalam hal ini Alumnus Akper Adi Husada termasuk ada unsur kesetiaan. Kesetiaan merupakan tekad dan kesanggupan mentaati, melaksanakan dan mengamalkan sesuatu yang dipatuhi dengan penuh kesadaran dan tanggung jawab. ${ }^{4}$ Tekad dan kesanggupan itu di buktikan dalam sikap dan tingkah laku sehari - hari serta dalam melaksanakan tugas keperawatan di ruangan. Disini peran manajer keperawatan sangat mendukung motivasi kerja bawahannya untuk mencapai tujuan organisasi. Dalam upaya memotivasi kerja, pegawai di berikan kesempatan ikut berpartisipasi dalam menentukan tujuan yang akan dicapai. Manajer mengkomunikasikan segala sesuatu yang berhubungan dengan usaha pencapaian tugas dengan informasi yang jelas, pegawai akan mudah termotivasi kerjanya manajer jangan segan - segan untuk memberikan penghargaan (reward) pada pegawai yang berprestasi dalam pekerjaannya sehingga dapat meningkatkan motivasi kerja dan memberi semangat dalam memotivasi dirinya.

\section{SIMPULAN DAN SARAN}

\section{Simpulan}

Terdapat hubungan yang bersifat lemah antara motivasi kerja dengan kinerja alumnus Akper Adi Husada yang bekerja di RS Adi Husada Undaan Wetan, karena masih banyak faktor lain yang mempengaruhi kinerja selain motivasi antara lain sikap, situasi kerja, skala beban kerja dan kesetiaan. Namun motivasi sangat penting dalam mendukung kinerja perawat guna meningkatkan partisipasi dan semangat dalam bekerja.

\section{Saran}

Peneliti menghimbau agar motivasi kerja tetap ditingkatkan demi upaya meningkatkan produktifitas dan kreatifitas perawat dalam bekerja di lahan klinik terutama RS Adi Husada Undaan Wetan Surabaya.

\section{DAFTAR PUSTAKA}

1. Gillies, Dee Ann. 1996. Manajemen

Keperawatan Suatu Pendekatan Sistem. Edisi

2. Philadelphia. W.B Saunders Company.

2. Notoatmodjo Soekidjo, 2002. Metodologi Penelitian Kesehatan. Cetakan Kedua. Jakarta : PT. Rineka Cipta.

3. Nursalam, 2003. Konsep dan Penerapan Metodologi Penelitian Ilmu Keperawatan. Jakarta : Salemba Medika.

4. Yaslis Ilyas, 1999. Kinerja Teori, Penilaian dan Penelitian. Cetakan Pertama. Jakarta : FKM UI 